\title{
Philip Melanchthon's History of the Life and Acts of Dr Martin Luther
}

\author{
translated by Thomas D. Frazel \\ and annotated by Ralph Keen
}

\author{
HISTORY OF THE LIFE AND ACTS \\ OF THE MOST REVEREND DR MARTIN \\ Luther, Dr of true Theology, \\ written in good faith \\ by Philip Melanchthon
}

Certain poems have been added by John Policarius ${ }^{1}$ on the blessings which God through Luther bestowed upon the whole world. Including several distichs on the Acts of Luther, which were recounted in this same year. 1548.

Reverend Martin Luther gave us hope that he would relate the course of his life and the occasions of his struggles, and he would have done so if he had not been called from this mortal life into the everlasting converse of God and the heavenly Church. But a lucidly written contemplation of his own private life would have been useful, for it was full of lessons which would have been useful in strengthening piety in good minds, as well as a recitation of events which could have made known to posterity about many things, and it would also have refuted the slanders of those who, either incited by princes or others, fictitiously accuse him of destroying the dignity of the Bishops, or that, inflamed by private lust, he broke the bonds of Monastic servitude.

He would have published these things, wholly and copiously set forth and commemorated by himself. For even if evilwishers were to reproach with that common saying, He himself blows his own pipe, nevertheless we know there was so much seriousness in him that he would have related the Account with the utmost fidelity. And many good wise men are still living, to whom it would have been ridiculous for another account to be mixed in, as sometimes happens in poems, since he knew they were aware of the order of these events. But because his day of death turned aside the publication of so important an account, we shall recite in good faith about the same matters those things which partly we heard from the man himself, partly those which we ourselves saw. 
There is an old family, with many descendants of moderate men, by the name Luther, in the district of the famed Counts of Mansfeld. The parents of Martin Luther first made their home in the town of Eisleben, where Martin Luther was born, then they moved to the town of Mansfeld, where his father, Johannes Luther, acted as Magistrate and was most cherished by all good men because of his integrity.

In his mother, Margarita, the wife of Johannes Luther, since all the other virtues of an honest Matron were seen coming together - modesty, fear of God, and prayer especially shown forth - the other honest women looked to her as an example of virtues. She answered me as I asked several times about the time of her son's birth that she remembered the day and hour exactly, but she was uncertain of the year. However she affirmed that he was born the night of 10 November after eleven o'clock, and the name Martin was given to the infant, because the next day, on which the infant was brought into the Church of God through Baptism, had been dedicated to Martin. ${ }^{2}$ But his brother Jacob, an honest and upright man, said the family believed that the year of his birth was AD 1483 .

After he was at the age capable of learning, his parents had diligently accustomed their son Martin to the knowledge and fear of God and to the duties of the other virtues by domestic instruction, and as is the custom of honorable men, they saw to it that he learned to read, and his father brought him, even as a quite young boy, to the elementary school of George Aemilius, who can be a witness to this story because he is still living. ${ }^{3}$

At that time, however, Grammar Schools in Saxon towns were of middling quality, so when Martin reached his fourteenth year, he was sent to Magdeburg along with Johannes Reineck, whose virtue was later so outstanding that he had great authority in these Regions. ${ }^{4}$ There was exceptional mutual kindness between these two, Luther and Reineck, whether by some concord of nature or whether rising from that companionship of boyhood studies; nevertheless, Luther did not remain in Magdeburg longer than a year.

Next in the school at Eisenach he studied for four years with a praeceptor who taught Grammar more correctly and skillfully than others; for I remember Luther praised his intelligence. He was sent to that city because his mother had been born of an honest and old family in those parts; here he completed grammatical study, and since the power of his intelligence was the most keen, and especially suited for eloquence, he quickly surpassed his coevals and easily surpassed the rest of the youths in the school, both in acquiring vocabulary and fluency in diction, as well as in the writing of prose and verse.

Therefore, having tasted the sweetness of literature, by nature burning with the desire for learning, he sought out the Academy, as the source of all learning. So great a power of intelligence would have been able to grasp all the arts in order, if he had found suitable Doctors, and perhaps both the gentler studies of Philosophy and attention in forming speech would have benefited in softening the vehemence of his nature. But at Erfurt he encountered the crabbed Dialectic of that age and quickly seized it, since by the sagacity of his intelligence 
he grasped the causes and sources of the precepts better than the rest of the boys. $^{5}$

And since his mind was eager for learning, he sought more and better things, and he himself read the many writings of the ancient Latin writers, Cicero, Virgil, Livy, and others. He read these, not as boys do, picking out the words only, but as the teaching of human life, or, since he looked at the counsels and sayings of these men more closely, and as he had a faithful and firm memory and read and heard many authors, the images were in sight and before his eyes. Thus he was therefore outstanding among the youth, so that Luther's intelligence was a thing of wonder to the whole Academy.

Decorated therefore with the degree of Master of Philosophy at the age of twenty, on the advice of his relatives, who judged that so great a power of intelligence and fluency should be brought forth into the light and for the Republic, he began the study of law. ${ }^{6}$ But a short time later, when he was twenty-one, suddenly, against the opinion of his parents and relatives, he went to the College of Augustinian Monks at Erfurt, and sought to be admitted. ${ }^{7}$ Once admitted, he soon learned the teaching of the Church not only by the most intense study, but he himself also gained self-mastery by the greatest severity of discipline, and he far surpassed the others in all the exercises of readings, disputes, fasts, and prayers. He was, however, by nature something I often marveled at, neither small nor weak in body, though he ate and drank little; I saw him on four consecutive days neither eat nor drink a thing the entire time, yet he remained completely strong; I often saw that on many other days he was content with a tiny bit of bread and fish per day.

This was the occasion of his starting in on that manner of life which he reckoned more suitable for piety and studies of the doctrine about God, as he himself told and many know. Often great terrors so suddenly terrified him as he thought more intently on the anger of God or the awesome examples of punishments that he almost went out of his mind. And I myself saw him, when he was overcome by tension in a certain debate about doctrine, go to bed in the neighboring cell, and when he repeatedly mixed that recollected idea with a prayer, he counted it all as sin, so that he would be forgiven for all. He felt those terrors either from the beginning, or most sharply in that year because he lost his companion who was killed in some sort of mishap.

Therefore not poverty but eagerness for virtue led him into this mode of monastic life, in which even if he daily learned the customary learning in the schools, and read the Sententiarii, ${ }^{8}$ and in public debates eloquently explained to amazed crowds labyrinths inexplicable to others, nevertheless, because he sought the nutriments of piety in that type of life, not renown for his intelligence, he put his hand to these studies as if they were a side interest, and he easily grasped those scholastic methods. Meanwhile he himself avidly read the sources of heavenly doctrine, namely the writings of the Prophets and the Apostles, in order to educate his mind about the will of God, and by faithful witnesses to nourish his fear and faith. He was moved by his own sorrows and fears to seek out this study more. 
And he told that he was often encouraged by the conversations of a certain old man in the Augustinian College at Erfurt, when he set forth his worries to him. He heard the old man discuss much about faith, and he said that he was led to the Creed, in which it is said, I believe in the forgiveness of sins. That old man had interpreted this Article so that it should be believed not only in general, i.e. forgiven by some persons or others, as they believe Demons are forgiven by David or Peter, but that it was a commandment of God that each one of us individually believe his sins are forgiven. And he said that this interpretation was confirmed by a saying of Bernard, and then he pointed to a place in his sermon on the Annunciation, where there are these words, But you should also believe what is given to you in your sin, namely the testimony that the Holy Spirit puts in your heart, saying 'Your sins are forgiven.' For the Apostle thinks thus, that man is gratuitously justified through faith. ${ }^{9}$

Luther said he was not only strengthened by this statement, but even forcibly reminded of the whole passage of Paul, who so often hammers home this saying, that we are justified by Faith. When he had read many treatises about justification, and then applied himself to Bernard's sermons and On Consolation of the Mind, he recognized the emptiness of the interpretations that he then held in his hands. Little by little, as he read and compared the sayings and lessons recorded in the Prophets and Apostles, and as he kindled his faith in daily prayer, he acquired more illumination.

Then he also began to read the works of Augustine, where he found many clear statements, in both the Commentary on the Psalms and the On the Spirit and the Letter, which confirmed this doctrine concerning faith, and he found consolation, which had burned in his own heart. ${ }^{10}$ Still he did not completely abandon the Sententiarii; he was able to recite Gabriel ${ }^{11}$ and D'Ailly ${ }^{12}$ by memory almost word for word. He read for a long time and thoroughly the writings of Occam, ${ }^{13}$ whose perspicacity he preferred to that of Thomas and Scotus. He also carefully read Gerson, ${ }^{14}$ but he read all the works of Augustine frequently, and remembered them the best.

He began this most intense study at Erfurt, where he stayed for four years at the Augustinian College.

At this time, because Reverend Staupitz, ${ }^{15}$ who had helped the beginnings of the Academy of Wittenberg, was eager to stimulate the study of Theology in the new Academy, and since he had had confidence in Luther's intelligence and learning, he brought him to Wittenberg in 1508 when Luther was already twenty-six. Here, amidst the daily exercises and lectures of the School, his intelligence began to shine even more. And since wise men, Dr Martin Mellerstadt ${ }^{16}$ and others, would listen to him attentively, Mellerstadt often said that there was so great a power of intelligence in that man, that he plainly foresaw that he would change the common form of learning, which was the only one being transmitted in the Schools at that time.

Here he first commented on Aristotle's Dialectic and Physics, yet all the while not dropping that eagerness of his for reading Theological writings. After three years he set out for Rome, because of controversy among the Monks, 
when he returned that same year, at the expense of Duke Frederick, the Elector of Saxony, in the usual manner of scholars he was adorned with the rank of Doctor, as we customarily say. For he had heard Luther debating, and had marveled at the power of his intelligence, the powers of his speech, and excellence of his explications of matters in debates. And so that you might see that the rank of Dr was conferred on him for a certain maturity of judgment, you should know that this was the thirtieth year of Luther's life. He himself used to tell that Staupitz ordered him, when he was running away and refusing, to let himself be adorned with this rank, and that Staupitz jokingly said that God had a lot of work to do in the church, and would be able to use Luther's help. This statement, even if it was said jokingly, nevertheless was true, as it presaged many changes.

Afterwards he began to comment on the Epistle to the Romans, ${ }^{17}$ next the Psalms; ${ }^{18}$ he so illuminated these writings that, as light after a long, dark night, so new doctrine seemed to appear, by the judgment of all pious and prudent men. Here he pointed out the essential point of the Law and the Gospel, there he refuted the error, which held sway at that time in the Schools and in debates, which taught that men merited forgiveness of sins by their own works, and that men were justified before God by discipline, as the Pharisees taught. Accordingly Luther called the minds of men back to the son of God, and, like the Baptist, he showed that the lamb of God, who took away our sins, freely forgives sins on account of the Son of God, and therefore this favor must be accepted by faith. He also explained other parts of ecclesiastical doctrine.

These beginnings of the greatest things gave him great authority, especially since the teacher's character was one with his teachings, and his speech seemed born, not on his lips, but in his heart. This admiration of his life produced great changes in the minds of his audience, so that as even the Ancients said, His character was, almost, so to speak, the strongest proof. Wherefore, when he later on changed certain accepted rites, honorable men who knew him were less vehemently opposed, and, in those statements in which they saw, with great sadness, the world torn apart, they gave assent to him on account of his authority, which he had previously acquired by the illustration of good things and by the sanctity of his morals.

Neither did Luther back then change anything in the rites - rather he was a severe guardian of discipline - nor did he have anything to do with the harsh opinions then current. But he was more and more explaining that universal and absolutely necessary doctrine to all, about penitence, the remission of sins, faith, and the true consolations in the cross. By the sweetness of this pious doctrine all were strongly won over, and what was pleasing to the learned, as if Christ, the Prophets, and Apostles were led out of darkness, jail, and squalor, the essential point of the Law, and the Evangelists, the promises of the Law, and the promises of the Gospel, of Philosophy and the Evangelists, became apparent, [and] something certainly not found in Thomas, Scotus, and others like them, the essential point of spiritual righteousness and political affairs. 
He approached the understanding of Latin and Greek, to which the studies of his youth had already been invited by the writings of Erasmus, ${ }^{19}$ wherefore, since the gentler type of his doctrine had been shown, many men endowed with good and free minds began to abhor the barbaric and Sophistical doctrine of the Monks.

Luther himself began to give himself to the studies of Greek and Hebrew, so that having learned the peculiar quality of the language and the diction, and doctrine drawn from its sources, he might be able to judge more skillfully.

When Luther was in this course of study, venal indulgences were circulated in these regions by Tetzel the Dominican, a most shameless sycophant. ${ }^{20}$ Luther, angered by Tetzel's impious and execrable debates and burning with the eagerness of piety, published Propositions concerning indulgences, ${ }^{21}$ which are extant in the first volume of his writings, and he publicly attached these to the church attached to Wittenberg Castle, on the day before the feast of All Saints, 1517. This Tetzel, true to his character, and also hoping he would obtain favor before the Roman Pontiff, calls his Senate, a few Monks and Theologians lightly imbued in some way or other with his own Sophistry, and orders them to cobble something together against Luther. Meanwhile Tetzel himself, so that he would not be a 'silent actor,' brandishes not just Public Debates, but thunderbolts, cries aloud everywhere that this Heretic must be condemned to fire, even publicly hurls Luther's Propositions and Debate concerning indulgences into flames. ${ }^{22}$ These ravings of Tetzel and his Henchmen place the necessity on Luther of more expansively discussing these matters and of preserving the truth.

These were the beginnings of this controversy, in which Luther, as yet suspecting or dreaming nothing about the future change of rites, was not certainly not completely getting rid of indulgences themselves, but only urging moderation. Wherefore they falsely accuse him when they say that he began for a praiseworthy reason, so that afterwards he could change the State and seek power either for himself or for others.

And he was so removed that, suborned or incited by princes, just as the Duke of Braunschweig wrote, that even Duke Frederick, looking far ahead, lamented that struggles were set in motion, although the beginning was about a praiseworthy matter, nevertheless little by little this flame would wander wider, as is said in Homer about the Quarrel, From small fear at first, soon it lifted itself into the upper air.

Since Frederick was the one Prince of our era both the most fond of public tranquility and the least selfish, and since he was especially accustomed to set forth plans for the common well-being of the world, it can be seen from many matters [that] he was neither an instigator nor an applauder of Luther, and he often made known his own distress, which he continually proclaimed, fearing greater dissensions.

But, not only following profane judgments, which bid that the gentle beginnings of all changes be most quickly suppressed, but also employing the divine precept in decision, which bids the Gospel to be heard, and which forbids 
opposing the known truth, and calls blasphemy horribly damned and condemned by God, a stubborn adversary to the truth, the wise man did what many other pious and learned men did: he yielded to God, and carefully read those things which were written, and those which he judged to be true, he did not want to do away with.

For I know that he often ascertained the opinions of the erudite and learned about these very matters, and in that Convention that the Emperor Charles $\mathrm{V}$ held in the city of Cologne after his coronation, affectionately bade Erasmus of Rotterdam to say freely whether he reckoned Luther was wrong in these controversies about which he had especially discoursed. Then Erasmus clearly said that he thought Luther was correct, but that he wanted mildness in the man. Wherefore, when Duke Frederick afterward wrote to Luther with the greatest seriousness, he strongly encouraged him to lighten the harshness of his pen.

It is agreed that Luther would have promised Cardinal Cajetan ${ }^{23}$ that he would be silent, if he had also enjoined silence on his opponents. From which it can clearly be seen that indeed at that time he had not yet shown that he would in turn set other struggles in motion, but that he was desirous of tranquility, but little by little he was dragged into other subjects, with the uneducated challenging him on all sides with the Scriptures.

Therefore Debates followed concerning the difference between divine and human laws, concerning the abominable profanation of the Supper of the Lord in its sale and application for others (i.e. offering masses for other people). Here the entire theory of Sacrifice was set forth and the use of the Sacraments was shown. And when pious men in the Monasteries now heard that they must flee from Idols, they began to depart from their impious servitude.

Therefore Luther added to the explanation of the doctrines on penance, the remission of sins, faith, and indulgences, also these topics: the difference between divine and human laws, the doctrine on the use of the Supper of the Lord and the other Sacraments, and concerning Prayers. And these were the principal points of contention. Eck proposed an investigation of the power of the Roman Bishop, for no other reason than to fire up the hatred of the Pontiff and the Kings against Luther. ${ }^{24}$

He kept the Apostolic, Nicene, and Athanasian Creeds [as the] most pure, next he fully explained in many writings what should be changed in human rites and traditions, and why; and it is clear what he wanted to be kept and what form of doctrine and administration of the Sacraments he approved of from the Confession which Duke Johannes Elector of Saxony, and Prince Philip Landgraf of Hesse and others presented at the Diet of Augsburg to Emperor Charles V in 1530. The same is clear from the very rites of the Church in this city, and from the Doctrine which sounds forth in our Church, whose principal matter is manifestly expressed in the Confession. I therefore make mention of the Confession again not only for the pious to contemplate which errors Luther reproached and which Idols he removed, but also so that they might understand that it embraces a universal, necessary teaching of the Church, that he restored 
purity in the rites, and that he taught Examples for renewing the Church to the pious. And it is useful for posterity to know what Luther approved.

I do not want to recollect in this place those who first publicly offered both parts of the Lord's Supper, and those who first ceased saying private Masses when the Monasteries were first abandoned. For Luther had discussed only a few things about these matters before the Diet which was in the city Worms in 1521 . He himself did not change the rites, but when he was not there, Karlstadt and others changed the rites: $:^{25}$ and since Karlstadt did certain things more tumultuously, when Luther returned, he declared what he approved or disapproved with clear testimonies of his opinion. ${ }^{26}$

We know that political men vehemently detest all changes, and it must be admitted that even when upheavals are set into motion by the most just causes, something evil is always to be lamented in this sad disorder of human life. But nevertheless in the Church it is necessary that the command of God is to be preferred to all human things. The Eternal Father said this statement about his Son: This is my beloved Son, listen to this man, and he threatens everlasting wrath against blasphemers, that is, against those who endeavor to obliterate the known truth. Wherefore Luther's pious and necessary duty was, especially since he taught the Church of God, to reproach destructive errors which Epicureans were heaping up with even new shamelessness, and it was necessary for those who heard to give assent to the one teaching correctly. If change is truly hateful, if there are many discomforts in discord, as we see with great sadness that there are, the blame is on those who in the beginning spread the errors, as well on the men who now defend those errors with a diabolic hatred.

I recall these things not only to defend Luther and his followers, but also so that pious minds might ponder at this point in time and hereafter what is and always was the governance of the true Church of God, how God through the word of the Gospel selects the eternal Church for himself out from that mass of sin, that is from the great dregs of men, among whom the Gospel shines forth like a spark in the darkness. Just as in the time of the Pharisees Zacharias, Elizabeth, Mary, and many others were guardians of the true doctrine, so even before these times there were many, who, duly calling upon God, were more clearly keeping the doctrine of the Gospel, while others were less so. Such was also that old man, about whom I spoke, who often encouraged Luther as he was contending with fears, and who, in another way, was a teacher to him in doctrine and faith. Just as we should pray God with fervent prayers that he successively save the light of the Gospel in many men, so Isaiah prays for those his followers, Seal the law in my disciples. This remembrance then shows that counterfeit superstitions are not lasting but are rooted out by divine providence. Since this is the reason for the changes, care must be taken that errors are not taught in the Church.

But I return to Luther, just as he entered upon this cause without desire for private gain, even if his nature was ardent and irascible, nevertheless he was ever mindful of his own function - he only battled by teaching and avoided taking up arms, and he wisely distinguished the conflicting duties of a Bishop 
teaching the Church of God, and of Magistrates, who restrain the multitude by the sword.

Wherefore, since at different times the Devil, who is eager to destroy the Church with scandals and to insult God, and as he is The evil one showing malignant joy, takes pleasure from the sins and downfall of pitiable men, [and] has inflamed factious natures to foment disturbances, such as Müntzer and those like him, ${ }^{27}$ he most vehemently condemned those ragings, and he not only adorned the dignity and all the bonds of the political order but also defended it. When, however, I ponder how many great men in the Church have often wandered in mind in this matter, I am of the distinct opinion that his heart was governed by not only human earnestness but also by a divine light, because he stayed so firmly within the boundaries of his office.

Accordingly he cursed not only the factious Doctors of this age, Müntzer and the Anabaptists, but also those Bishops of Rome, who most boldly and shamelessly asseverate in the Decrees they had written that not only was the duty of teaching the Gospel enjoined on Peter but Imperial politics were even handed over to him.

Accordingly he was an exhorter to all to give to God the things of God, to Caesar the things of Caesar, that is, to worship God with true penance, with the recognition and propagation of true doctrine, with true prayer, and with the responsibilities of a good conscience. Indeed let each man respectfully obey his own state in all civil duties on account of God. And Luther himself was in fact of such a kind: he gave to God the things of God, he taught properly, he called on God properly, he had also the other necessary virtues in a man which are pleasing to God, and finally, in political custom he most consistently avoided all factious plans. I judge that these virtues are so seemly that greater ones cannot be wished for in this life.

And although the virtue of the man himself who reverently used the gifts of God is praiseworthy, nevertheless it is especially necessary to give thanks to God, because through him He restored the light of the Gospel to us and the memory of its doctrine was preserved and propagated. Nor am I disturbed by the shouts of Epicureans or Hypocrites who either laugh at or curse the obvious truth, but I declare as true that this very doctrine which sounds out in our Churches is the uninterrupted concord of the Universal Church of God and that prayer and life are governed by the requisite admission of this doctrine. Accordingly [I say] that this is the very doctrine about which the Son of God speaks, If any man loves me, he will keep my word, and my Father will love him, and we shall come to him and build a dwelling in his house. For I am speaking of the highest Doctrine as it is understood and explained in our Churches by the pious and learned. For even if some men at times explain something more properly and elegantly while other men explain less so, or one man speaks sometimes in a less refined manner than another, nevertheless there is agreement among the pious and educated about matters of the greatest importance.

And as I often think hard about the doctrine of all times [handed down] by the Apostles uninterruptedly from that time, after the initial purity four 
prominent changes of doctrine seemed to have followed. First is the age of Origen. ${ }^{88}$ However many there were who taught correctly, still I single out Methodius for condemning the decisions of Origen, who turned the gospel into philosophy in the minds of many, pouring out his conviction that moderate mental training earns forgiveness of sins, and that this is the righteousness about which the verse 'The righteous will live by his faith' speaks. This age almost completely lost the essential point of the Law and the Gospel and gave up the Apostolic teaching. For it did not keep the natural meaning in the words 'letter,' 'spirit,' 'righteousness,' 'faith.' And having lost the peculiar nature of words which are the signs of things, it is necessary to fabricate other things. Pelagius's error, which spread widely, arose from these seeds. And since the Apostles had given the pure doctrine or the pellucid and most health-giving sources of the Church, Origen filled the sources with a great deal of mud.

So that the errors of this age would be corrected from at least some part, God roused up Augustine, ${ }^{29}$ who moderately cleaned the sources again; nor do I doubt, if this man would have been the Judge of the disputes of this age, that we would be reckoned straight away by the same vote. He clearly thought precisely as we do about the gratuitous remission of sins, justification by faith, the use of the Sacraments, and the indifferent things. However, even if here he explained more eloquently or properly what he wanted, there less so, nevertheless if a Reader would bring brilliancy and skill in judging him, he perceives that he thinks as we do. For the fact that our adversaries sometimes cite Augustine against us after having picked out sayings from him, and that they make an appeal to the fathers with a great shout, does not mean they do this out of eagerness for the truth and antiquity, but they deceitfully manufacture the authority of the ancients with the idols before them, those idols which had been unknown until a later age.

But nevertheless it is certain that the seeds of superstitions existed in that age of the Fathers. On that account Augustine decided certain things about prayers, even if he spoke less uncouthly about these than others did. However, the pollutions of one's own age always sprinkle some of the follies with even individuals' goods, because just as we are well disposed to our country, so to the rites at hand on which we were brought up, and that saying of Euripides is absolutely correct, Everything familiar is pleasant. Would that all those who boast that they follow Augustine actually return to the uninterrupted idea, and, if I may put it this way, the heart of Augustine, and not merely deceitfully twist mutilated sayings into their own beliefs.

And light having been restored to the writings of Augustine, it benefited posterity, for thereafter Prosper, Maximus, Hugo, and others like them who direct studies, even to the age of Bernard, follow the principle of Augustine. Meanwhile nevertheless the Empires and wealth of the Bishops were growing, and just as the age of the Titans followed, profane and uneducated men reign in the Church, some of whom had been refined in the arts of the Roman court or in the doctrine of the law court.

So Dominicans and Franciscans arose, who, when they saw the luxury and 
wealth of the Bishops, loathed profane morals, set up a simpler way of life and shut themselves up as if in the jails of discipline. But at first their inexperience increased the superstitions, then, when they saw that the studies of the men in the Schools were turned solely toward forensic doctrine, because already at Rome lawsuits were increasing the power and wealth for many, they themselves endeavored to call men back to theological studies but they lacked a plan. Albert and those like him who had given themselves over to the doctrine of Aristotle began to transform the doctrine of the Church into philosophy. And this fourth age poured not only mud but moreover poisons into the Gospel's sources by approving ideas - plain idols - and there is so great a labyrinth and false opinions in Thomas, Scotus, and those similar that sounder theologians have always wanted another simpler and purer kind of doctrine.

Nor can it be said without remarkable shamelessness that there was no need for the change of this doctrine, since it was evident that the great part of the Sophisms in those public debates were in no way grasped by those who grew old in that kind of doctrine. Then the idolmania is openly confirmed when they teach that the eucharistic sacrifice is efficacious simply by being performed, when they excuse the invocations of statues, when they deny that sins are gratuitously forgiven by faith, when out of human Ceremonies they make those of good conscience into an executioner, and finally there are many other things more loathsome and blasphemous, which, when I think about them, I shudder with my whole body.

Therefore let us give thanks to God the eternal Father of our Lord Jesus Christ, who wanted the dirt and poisons to be driven out again from the Gospel sources by his servant Martin Luther, and he restored the pure doctrine of the Church, wherefore it is proper for all pious thinking men in the whole world to join prayers and lamentations together and to beg with burning hearts that God strengthen that which he has done among us on account of his holy temple. This is your word and promise, O living and true God, the eternal Father of our Lord Jesus Christ, creator of all things and of the Church, On account of my name I shall pity ye, on account of me, On account of me I shall not be reproached. I pray You with my whole heart on account of your glory and the glory of your Son always to unite to you the eternal Church also among us by the word of your Gospel, and on account of your Son our Lord Jesus Christ crucified for us and resurrected, intercessor and suppliant, and to guide our hearts by the holy Spirit, so that we may truly call upon you and fulfill the duties pleasing to you.

Guide also the studies of doctrine and govern and preserve these governments and their order, which are the homes of your Church and disciples, since you created the human race for this reason, so that you be known and invoked by men, wherefore you also made yourself known by brilliant witnesses, may you not allow these battles in which your doctrine sounds forth to be destroyed. And since your Son our Lord Jesus Christ, as he was about to undergo his trial, prayed for us: Father, sanctify them in truth, your Word is truth. We join our prayers to the plea of this our Priest and we beg together with him that 
your doctrine may ever shine out in the human race, and that he govern us. We heard Luther also daily praying these, and during these prayers his soul was calmly called from his mortal body, when he had already completed his sixty-third year.

Posterity has many monuments of the man's teaching and piety. He published Teachings in which he embraced the saving doctrine and the necessity for men instructing good minds about penance, faith, the true fruits of faith, the use of the Sacraments, the essential point of the Law and the Gospel, the dignity of the political order, and finally the principal Articles of doctrine which must of necessity be present in the Church. Next he added Cross-examinations in which he refuted many destructive errors among men. He published Interpretations as well, that is, many commentaries on the Prophetic and Apostolic writings, in which genre even his opponents admit that he surpassed the extant commentaries of all.

All pious minds see that these merits are great, but indeed, the translation of the old and new Testament equaled these works in usefulness and labor, in which there is such great clarity that instead of a Commentary the very German reading itself can exist, which does not, however, stand alone, but has the most learned notes added to it, and the summaries of individual sections which teach the most important part of the heavenly doctrine and which educate the Reader about the kind of style, so that from the very sources themselves good minds would be able to take solid witnesses of doctrine. For Luther did not want to detain them in his own writings but to lead forth the minds of all to the sources. He wanted us to hear the word of God itself, and by this way he wanted true faith and prayer to be kindled in many, so that God be truly worshiped and many men be made inheritors of everlasting life.

It is fitting to publish with thankful mind this purpose and these labours so great, and to remember them as an example so that each of us also for our own sake will be eager to adorn the Church. For the whole of life and all the studies and plans of life must be especially referred to these two ends: first so that we embellish the glory of God; next that we benefit the Church. About the one of which Paul says, Do ye all for the glory of God. About the other Psalm 122, Ask ye peace for Jerusalem. And the most pleasing promise is added in the same verse, Those who love the Church will be happy and blessed. May these heavenly commands and these promises invite all men to learn the teaching of the Church correctly, may they love the ministers of the Gospel and the beneficial Doctors, and may they bring eagerness and dedication to spreading the true doctrine and to preserving the harmony of the true Church.

\section{The deeds}

of Reverend Father Dr Martin Luther in the Assemblies of Princes at Worms before the Emperor Charles V, the Princes, Electors, and the nobility of the Empire follow.

In the Year of Our Salvation 1521, on the Tuesday after Misericordia Domini 
Sunday (Second Sunday after Easter), Dr Martin Luther entered Worms, called by Emperor Charles, he the fifth King of the Spaniards of [that] name, Archduke of Austria, etc., who in the first year of his Reign celebrated the first gathering of Princes in that royal city. ${ }^{30}$

However, three years before, when Dr Martin had presented at Wittenberg in Saxony certain paradoxes against the tyranny of the Roman Bishop to be debated (which nevertheless meanwhile were censured, condemned, and burned in different ways by the papists, yet refuted by no one either by Scriptures or by logical arguments), the matter began to incline toward a disturbance, as the people watched the cause of the Gospel against the Clerics. And for this reason it seemed good, with the Roman Legates stirring things up, that Luther himself be summoned by the Imperial Herald, and he was led in this by the Emperor and the princes, who gave letters of safe passage. He was summoned, he came, and he stopped at the Senate of the soldiers of Rhodes, or [as] they are called, of the German order, where he stayed in an inn and was greeted and sought after even late into the night by many Counts, Barons, honored Cavalry Officers, and Nobles, Priests and Laymen.

But to many men both of the opposing party and to others his arrival happened completely contrary to opinion, for even though he had been summoned by Imperial messenger and by letters given for public safety, nevertheless because, a few days before he came, his books were condemned by letters posted publicly and privately, no one thought that he would arrive if he had already been condemned by this judgment.

And when in the neighboring town of Oppenheim, where Luther first learned these things, a deliberation was held by his friends and many of them concluded that he should not expose himself to danger, since he saw that these beginnings were done against a given promise, with all listening, he himself responded with a courageous spirit, 'Because I was called, truly it was decreed and is right for me to enter the city in the name of the Lord Jesus Christ, even if I know that as many Devils are opposed against me as there tiles in all the houses of the entire world, etc.'

On the next day after his arrival, Wednesday, a nobleman, Master of the Imperial cavalry, Ulrich von Pappenheim, ${ }^{31}$ having been sent by the Emperor, came before luncheon, showing to Dr Martin the command of Emperor Charles that at the fourth afternoon hour he present himself before the Imperial Majesty, Princes, Electors, Dukes and the remaining Orders of the Empire, where he would hear to what he was summoned, which Dr Martin, as he ought, accepted.

And immediately after the fourth hour of this day, Ulrich von Pappenheim and Caspar Sturm, Imperial Herald, through Germany, came ${ }^{32}$ (this Sturm was the Truce-Officer by which Dr Martin had been called forth from Wittenberg and brought down to Worms) to accompany the very one called forth through the garden of the Rhodians' Senate, into the lodging of the Counts of the Palatinate. And so that Luther would not be exposed to the crowd which was great in the road to the Imperial house, he was led down through some hidden steps in the Auditorium. Nevertheless he was not hidden to many, who were 
barely prevented by force from entering, and many fell to blows in eagerness to see Luther.

When therefore he stood in the sight of the Imperial Majesty, the Princes, Electors, and Dukes, in short of every one of the Empire's orders who then attended on the Emperor, Dr Martin was at first admonished by Ulrich von Pappenheim not to say anything unless asked.

Then the Orator of the Imperial Majesty, Johannes Eck, of the general Official of the Bishop of Trier, in a loud and intelligible voice, first in Latin, then in German, by the order of the Emperor spoke and moved the following resolution against the man, or one similar in effect to it, which follows its manner.

'Martin Luther, the Sacred and unconquered Imperial majesty, on the advice of all Ranks of the Holy Roman Empire, orders you to be called hither to the seat of his Majesty, so that I may interrogate you about these two points: first, do you confess that these books before me (a bundle of his books in Latin and his writings in German had been displayed) which circulate under your name are yours, and will you acknowledge them as yours or not? And second, do you want to retract and renounce them and their contents or rather cling to them even more and acknowledge them?'

Here, before Luther responded, Dr Jerome Schurff, ${ }^{33}$ who was standing quite near Dr Martin, shouted out, 'Let the books be given a name.' This Official of Trier read out by name from the books of Dr Martin Luther those which were all issued at Basel, among which also were counted the Commentaries on the Psalter, the Treatise on good works, the Commentary on the Lord's prayer, and, in addition to these, other non-disputatious Christian treatises.

After these and to these Dr Martin gave these answers back in Latin and German: 'By the Imperial Majesty two things are proposed to me: first, whether I wish to acknowledge as mine all the books having my name; second, whether I wish to defend or in fact to denounce something from those writings which were written and published up to this point by me. To which I shall respond as briefly and correctly as I can.

To begin with, I cannot help but embrace as my own the books already named and I shall never indeed deny anything of them.

Next, so that I may set forth what follows, whether I want to defend everything in an equal degree or to renounce, because the investigation is about faith and the salvation of souls, and because it concerns the divine word than which nothing is greater in heaven as on earth, which we should all rightly revere, it would have been bold and hazardous as well if I published something unconsidered, since I might say either more than the truth or less, and thus come under the judgment of Christ when he said, "Who denies me before men, I shall also deny him before my Father who is in the heavens." ${ }^{44}$ Therefore I ask, and especially humbly, of the Imperial Majesty for time for deliberating about this case, so that I may satisfy the interrogator without injury to the divine word and danger to my soul.'

From that a deliberation of the Princes began, which the Official of Trier 
reported thus: 'Even if now you, Martin Luther, were able to perceive sufficiently from the Imperial order to what you have been summoned, even though you are unworthy to receive a long delay for thinking about this case, nevertheless, out of inborn clemency, the Imperial Majesty grants one day for your contemplation, in order that tomorrow at the same hour you may appear in person and not set forth your thought in writing but relate it orally.'

After these words Dr Martin was brought back to his inn by the Herald. In which matter, in order that something not be omitted, between going to hear the Emperor's order and when Luther was already in the very assembly of nobles, he was strongly reminded by others in other words to be brave, to act manfully, and not to fear those who were able merely to kill his body, but were not able to kill his soul, but rather to fear that one who could send both his soul and body into hell. Also: When you stand before Kings, do not ponder what you say, for it will be given to you at that hour, etc.

On the following Thursday, after four in the afternoon, the Herald came and, taking Dr Martin, led him into the Palace of the Emperor, where he remained until six because the Princes were occupied, anticipating a large crowd of men, with himself spending time before the throng. And when all were assembled and Dr Martin stood before them, the Official sent forth these words.

'Martin Luther, yesterday evening the Imperial Majesty told you this hour, since you indeed openly acknowledged the books which we identified yesterday as yours. But to the question, "Do you want something of yours to be considered null and void, or do you approve everything which you acknowledge?", you sought deliberation, which is now at its end, even if by law you ought not have demanded more time for thinking, since you knew all along why you were called. And it was agreed by all that the business of faith is so certain that each one having been summoned at whatever time could give back his sure and unchanging explanation, much more should you, so great and so well-trained a professor of Theology. Come, at least answer the Emperor's demand, whose liberality you enjoyed in having time for thinking. Do you want to admit that all the books are yours? Or do you want to retract something?' The Official said these things in Latin and German.

Dr Martin himself responded in both Latin and German, albeit humbly, not clamorously, and modestly, nevertheless not without Christian ardor and steadfastness, and in such a way that his opponents desired a speech and a spirit more disheartened. But much more eagerly they awaited a Retraction, which a few had come to expect after the extra time for deliberating.

Then he replied in this way.

'Most Serene Lord Emperor, Most Distinguished Princes, Most Merciful Lords, obeying the limit determined for me yesterday evening I appear, beseeching through the mercy of God, that your most serene Majesty, and your most distinguished Lordships deign to hear mercifully this case, as I hope, in justice and truth. And if through my inexperience I have not given worthy titles to someone or I have erred in some way or other in courtly manners 
and actions, kindly forgive since I am a man experienced not in Palaces but in the corners of Monks, who is able to testify nothing else about myself than that by that ingenuousness of soul I have learned and written only this; that I should look only to the glory of God and the genuine education of the faithful of Christ.

'Most serene Emperor, Most distinguished Princes, Most Merciful Lords, to those two Articles proposed to me yesterday through your Most serene Majesty, namely, Whether I acknowledge the books examined and published under my name as mine and whether I want to persist in these defenses or to retract, I gave my prepared and clear answer, concerning the previous Article, in which I continue steadfastly, and I shall continue into eternity, that those books are manifestly mine and published under my name by me, unless perhaps in the meantime it happened that either by the cunning of rivals or by churlish wisdom something in them was changed or was perversely excerpted. For clearly I do not acknowledge anything else, only that which is mine only and written by me alone, without any other person's interpretation. To the second I would respond; I ask that your Most serene Majesty and your Lordships deign to turn your attention. My books are not all of the same type: For there are some in which I handled the piety of faith and morals so directly and Evangelically that my Opponents themselves are forced to admit that those books are useful, blameless, and clearly worthy of a Christian reading. But the Bull, although harsh and cruel, declares some of my books harmless, but then also condemns others with an absolutely monstrous judgment. And so if I were to begin to retract those, I beseech you, what would I do, unless I were the one man of all mortals to condemn that truth, which Friends and Enemies equally acknowledge, the only man of all fighting against a united acknowledgment?

There is another type (of my writing) which attacks the Pope and the doctrine of the papists, just as against those who by their own doctrines and worst examples have desolated the Christian world in both directions by an evil of the soul and the body. For no one can either deny or dissemble this, since the witnesses are the experiences of everyone and the complaints of all men that not only have the consciences of the faithful been most terribly entrapped, harassed, and tortured through the laws of the Pope and the doctrines of men, but in particular the money and properties, especially in this glorious nation of Germany, have been devoured by an unbelievable Tyranny, and are devoured to this day without end and in shameful ways: since nevertheless they themselves by their very own laws (as in distinctio 9 and 25, quaestio 1 and 2) ${ }^{35}$ take care that laws of the Pope and doctrines contrary to the Gospel or the sayings of the Fathers are to be reckoned erroneous and false.

If I then retracted these books I would be doing nothing other than strengthening this tyranny and letting godlessness in through the windows and doors, giving it even more room and freedom for destruction. And the enemy would become rich and powerful, for all his evil could roam wider and with more impunity than it even dared up to this point, in a manner all the 
more intolerable to the poor multitude, for they would believe that my retraction, like a public proclamation, bolstered and strengthened him, especially if he boasted that he had been made that way by me on the authority of your severe majesty and the whole Roman Empire. O good God, how great a cover for wickedness and Tyranny I would then be. There is a third type of them, which I wrote against some private and individual (as they call [them]) persons, against those naturally who endeavored to defend the Roman Tyranny and to destroy the piety taught by me.

Against those men I admit that I was harsher than is fitting for my religion or calling, but I am not making myself some kind of saint, and I am not discussing my life but the teaching of Christ.

Nor is it honest for me to retract those, because by this retraction it would again happen that Tyranny and impiety would reign by my patronage and rage more violently against the people of God than they ever reigned.

Nevertheless, because I am a Man and not God, I am not able to support my books by another patronage than my Lord himself Jesus Christ supported his own doctrine, who, when he was before Annas and was asked about his doctrine and received a blow from the officer, said: If I have spoken badly, produce the evidence about the evil. If the Lord himself, who knew that he was not able to sin, did not refuse to hear evidence against his own doctrine, even from the most worthless servant, so much more should I, who am a piece of dirt and unable to do anything but sin, seek out and ask if anyone wishes to offer evidence against my doctrine. And so I ask through the mercy of God, Most Serene Majesty and your Most Exalted Lords, for someone finally, either the highest [ranked] or the lowest be able to give evidence, refute the errors, gain the upper hand by the Prophetical and Apostolic writings, for I will be the most prepared, if I shall have been taught, whatever error to retract, and I will be the first to cast my books into the fire.

From these I reckon that it is made clear that I have considered and reflected on the risks and dangers enough, or on the passions and disagreements stirred up in the world on the occasion of my doctrine, about which I was gravely and forcefully warned yesterday. Clearly that condition in matters is the most pleasing of all to me, to see on account of the word of God passions and disagreements brought about, for He is the way, the outcome and result of the word: For he said, I did not come to bring peace but a sword, For I came to divide man against father, etc. ${ }^{36}$

Accordingly we must ponder, since our God is wonderful and terrible in his counsels, lest by chance that which is attempted in such great studies, if we begin from the condemned word of God, turns afterwards rather into an intolerable flood of evils, and what must be avoided lest the Reign of this best Youth Prince Charles (in whom after God there is much hope) be made misfortunate and inauspicious.

'I would have been able to demonstrate the matter more fully by Examples from scripture, about Pharaoh, the King of Babylon, and the Kings of Israel, who back then most especially destroyed themselves, even though they were 
eager to pacify and stabilize their Reigns by the wisest counsels. For it is he himself who grasps the crafty in his cunning, and he overturns mountains before they know. And so the work of God is to fear.

I do not say these things because there is need either for my doctrine or my warning in these whirlwinds so great, but because I ought not to turn aside the obedience owed my Germany. And I entrust myself to these your Powers and to your most Serene Majesty, humbly asking that they not permit me to be rendered hateful to them by the efforts of my Adversaries without cause. I HAVE SPOKEN.'

To these words, the Orator of the Empire scornfully said that Luther did not respond to the point, nor ought be called into question things which long ago in Councils had been condemned and defined. For that reason a simple and not complicated response was asked of him: Whether he wanted to retract or not?

Here Luther said: 'Since your most Serene Majesty and your Powers seek a simple response, I will give that, neither sophistical nor pointed in this way: Unless I shall be refuted by the testimonies of the scriptures or by manifest reason (for I believe neither in the Pope nor in the Councils alone, since it is agreed that they have rather frequently erred and have contradicted themselves), I am defeated by the writings prompted by me, and my conscience has been caught in the words of God; I am not able to retract nor do I want to do anything that goes against my conscience, no matter how safe or complete it may be.

Here I stand. I can do nothing else. God help me. Amen.'

The Princes took this oration delivered by Dr Martin into deliberation. The official of Trier began to attack the examination in this way.

'Martin, you have responded more impudently than befits your person, and moreover not to the proposition, you divide the Books in different ways, but in such a way that they all contribute nothing to the investigation. The fact is that if you would have recanted those in which the great part of your errors is, without a doubt the Imperial Majesty and his inborn clemency would not tolerate the persecution of the rest of them which are good. However you revive what the universal Council of Constance, assembled from the entire German nation, condemned, and you want to be defeated through scripture, in which you violently rant. For what does it matter to make known a new Controversy about matter condemned for so many ages by the Church and the Council? Unless by chance an explanation must be rendered to anyone about anything whatsoever. The fact is if he carried his point once that he must be refuted by scriptures, whoever contradicts the Councils and the ideas of the Church, we shall have nothing sure or fixed in Christianity. And this is the reason why the Imperial majesty asked of you a simple and plain response, either negative or affirmative. Do you wish to support all your writings as for the Church? Or to in fact retract something from them?'

Then Dr Martin asked that the Imperial Majesty allow him, led and protected by sacred scriptures, not to be forced to reply against his conscience without 
the manifest arguments of his opponents. The response sought was not sophistical, but simple and straightforward. He had nothing else than what he had given before: If the adversaries could not, by valid arguments, release his conscience from the errors (as they called them) to which it was captive, he would remain so entwined that he could never extricate himself. What the Councils have decreed is not completely true. On the contrary, the Councils have been mistaken and have often defined things contrary to themselves, therefore the argument of his opponents does not carry weight. He was able to point out that the Councils have gone wrong, he was not able to retract what was carefully plainly represented in scripture.

To which the official answered nothing, unless in the littlest points, no doubt, was he able to show that the Council had gone wrong. Dr Martin promised to show truly that he was able and willing.

When, however, darkness covered the entire auditorium each accordingly went home to his own home. A good part of the Spaniards followed after the man of God, Luther, as he was departing from the Imperial Majesty and Tribunal, with yells and mocking gestures in a great roar.

On Friday after Misericordia Domini, when the Princes, Electors, Dukes, and the remaining Ranks who were accustomed to be present at consultations had convened, the Emperor sent a Decree into the Senate containing the following: 'Our ancestors and the Christian Princes themselves, were in no way less obedient to the Roman Church than now Dr Martin Luther attacks it, and because he has taken it into his heart not to depart even a hair's width from his errors, we are not able deviate from the dignified Example of our Ancestors in defending the ancient faith and by bringing aid to the Roman seat: Martin Luther himself and his followers we charge with excommunication, and by other ways if they appear for the extinguishing [of Luther and his followers]. Nevertheless we are unwilling to violate the given and received security, rather we are about to take pains that he return preserved to the place whence he was summoned.'

This statement of Emperor Charles, the leading Electors, Dukes, society of the Empire, turned over through the entire Friday afternoon, even an entire Saturday followed, in this way, that Dr Martin as yet received no response from the Imperial Majesty.

In the meantime he was seen and visited by many Princes, Counts, Barons, Knights, Priests, religious and lay, nor can I say [how many] from the number of the commons; these ever occupied the senate nor were they able to get their fill by seeing. Two broadsides were even put up, one against Dr Luther, the other, as it seemed, for the Doctor. Though by a great many intelligent men, this very deed was craftily reckoned by his Enemies so that an occasion would be employed for annulling the given safe conduct, which the Roman legates were actively seeking.

The Monday after Jubilate Sunday (Third Sunday after Easter), before dinner, the Archbishop of Trier declared to Dr Martin that he should prepare to appear before him four days at the sixth hour before lunch, having again appointed a 
place. On St Gregory's Day, shortly before lunch, one of the clergy of the Archbishop of Trier returned to Luther, with the order of his Prince, seeking that on the next day at the hour recently designated he appear at the inn of his lord.

On Wednesday after the birth of St George, complying with the agreement, Dr Martin entered the inn of the Archbishop of Trier, led in by his Priest and the Imperial Herald, with those following him who traveled with him from Saxony and Thuringia as he came here, and some other close friends besides, where before the Archbishop of Trier [were] Joachim the Marquis of Brandenburg, Duke George of Saxony, the Bishops of Augsburg and Brandenburg, Count George, master of the Teutonic Order, Johann Bock of Strasbourg, and Drs Werdheymer and Peutinger.

Dr Vehus, from the clerics of the Marquis of Baden, ${ }^{37}$ began to speak and protested that Luther himself was not called in this, so that they would consult with him as if in a public debate or dispute, but only out of Christian charity and a certain mercy, the Princes obtained from the Imperial Majesty that they be permitted to encourage him mercifully and affectionately.

Then he said: 'The councils, even if they have decreed contradictory things, have not nevertheless decreed contrary things, Because if they had erred in the highest degree, if you will, on that account nevertheless they have not overthrown their authority, merely so much as anybody would want to strive against those things by his own sense.'

Inferring much from the Centurion and Zaccheus, even from human arrangements, from Religious ceremonial decrees, confirming that all those things were sanctified to restrain changes, according to the nature and change of the times, neither are the changes, according to the nature and change of the times, nor is the Church able to be without human arrangements. [He said that] the tree is known by its fruits. Nevertheless many good things are said to arise from laws. The fact is that St Martin, St Nicholas and many other saints attended councils.

Next, [he said that] Luther's books would rouse up tremendous disturbances and unbelievable uproars, because the common people misuse his book $O n$ Christian Freedom to cast off the yoke and lead disobedient lives. It has a very different meaning, namely that in believers there is one heart and one soul. Thus law and order are necessary.

Besides it must be considered that although he had written many good works, and without a doubt in good spirit, e.g. Concerning the Threefold Justice, and others, the Devil still works through hidden ambushes, so that all his works should be condemned for eternity. For one can judge rightly by the books he wrote most recently, just a one knows a tree by its fruits rather than its flowers.

Then he added words about the mid-day Devil and the work by walking in darkness and the flying arrow. The entire speech was exhortatory, full of rhetorical commonplaces about honesty, the utility of Laws, and conscience from the region of dangers, and communal and individual salvation. At the 
beginning, the middle, and the end he repeatedly stressed that this admonition was made with the most well-disposed will and a certain exceptional mercy by the Princes. Concluding, he added warnings in the Epilogue, saying that if he were to persist in the proposition, the Emperor would proceed to expel him from the Empire, admonishing him to reflect and weigh out these and the remaining things.

Dr Martin replied: 'Most Merciful and Illustrious Princes and Lords, Concerning that most merciful and kindly will, from which this admonition began, I thank you as humbly as I can. For I realize that I am a little man, not worthy of being warned by Princes so great.'

Then he boldly proclaimed that he did not reproach all the Councils but only the Council of Constance, ${ }^{38}$ for this reason above all: because it condemned the word of God, which Jan Hus made manifest in the Article condemned there, that the Church of Christ is the company of the predestined. It is certain that the Council of Constance condemned this Article and thus consequently this Article of our faith: I believe in the holy Church, Universal. Accordingly he said that he was not able to recant and threaten his life and blood, therefore he was not now reduced to being forced to retract the evident word of God. For in this defending he ought to obey God rather than men.

And he said he was not able to avoid the Scandal of faith on this occasion, for the Scandal was twofold, of charity and of faith.

Of Charity, because it consists of morals and life, of Faith or, in truth, of doctrine, because it consists of the word of God, and he was not now able to avoid this, for it was not in his power to keep Christ from being the rock of scandal.

If the sheep of Christ were fed by the pure food of the Gospels, the faith of Christ truly preached, and the ecclesiastical Magistrates were truly good and pious, who would faithfully do their duty, there would be no need to burden the Church with human traditions etc. He knew that Magistrates and ones in power must be obeyed even though they lived evilly and unjustly. He knew that it must be yielded to one's own sense, and he taught this in his writings, and he would most obediently maintain all these, only he would not be driven to deny the word of God.

After Dr Martin left, the Princes discussed what they should answer to the man. Accordingly he was recalled into the dining-room; the Dr of Baden sought the earlier matters again, admonishing that he submit his own writings to the judgment of the Emperor and the Empire.

Dr Martin replied humbly and modestly that he neither allowed nor would he allow that he be said to have run away from the judgment of the Emperor, Nobles, and Ranks of the Empire. For he was so far from avoiding their examination through fear that he would allow his own [writings] to be weighed most exactly rather by the least [qualified], only let this be done by the authority of the divine word and sacred scripture. However, the word of God was so clearly in his favor that he could not waver unless he were instructed even better by the word of God. For St Augustine wrote that he had learned 
that this honor holds only in those books which are called Canonical, so he [said he] would believe the true ones; the Other Doctors in truth would be valued for ever so great sanctity or doctrine, if they wrote true things - [he said] only then would he believe them: On these points St Paul wrote to the Thessalonians, Examine everything, keep what is good. ${ }^{39}$ And to the Galatians: Even if an Angel comes from heaven and preaches something different, let him be anathema, and so he must not be believed: ${ }^{40}$ For that reason he humbly asked that they not urge his conscience bound by the chains of scripture and the divine word to deny the word of God so clear and [he asked] that they consider him committed and that they especially bring about before the Imperial majesty that he not be forced to do anything in this matter against his conscience, otherwise he would do everything most obediently.

As he was saying these things the Marquis of Brandenburg, Elector Joachim, asked him whether he had said that he would not yield unless refuted by sacred scripture.

Dr Martin replied: 'Even, most merciful Lord, by the clearest and evident proofs possible.' So when this Meeting was adjourned, while the rest of the Princes set out into the Senate, the Archbishop of Trier summoned Dr Martin to his own Dining-room, with Johannes Eck his official and Cochlaeus joining him: ${ }^{41}$ Dr Jerome Schurff and Nicholas Amsdorff ${ }^{42}$ were standing by Dr Martin Luther. There the Official then began to adduce proof just as a Sophist and a Canon Lawyer, defending the case of the Pope. [He said] heresies almost always arose from sacred writings, as Arianism from this passage of the Gospel: Joseph did not know his wife, until she bore his first-born. ${ }^{43}$ Next having progressed so far, in order to strive to tear loose this proposition, that the Church universal is the company of the Saints, he even dared to make wheat from tare, and limbs from the excrements of bodies. After making public these and similar ridiculous and worthless ideas, Dr Martin and Dr Jerome Schurff reproved them, soberly nevertheless, as having nothing to do with the matter itself. Johannes Cochlaeus sometimes making noise in the midst of this, tried to persuade Dr Luther to desist from what he began and to abstain completely from writing and teaching thereafter. At length they departed.

Around evening of the same day, the Archbishop of Trier announced to Dr Martin, through his agent Amsdorff, that the safe conduct was extended by the Emperor into two days, so that he would meanwhile be able to talk with him.

So on this next day, Dr Peutinger ${ }^{44}$ and Dr Baden would come to him and he himself would talk with him.

Therefore on Thursday, St Mark's Day, before Noon, Peutinger and Baden attempted to persuade Dr Martin to accept without reservation and completely the judgment by the Emperor and the Empire of his own writings.

He replied: He would do and allow everything if only they relied on the authority of sacred scripture: For otherwise he would commit to nothing. For God spoke through the Prophet, Do not trust in princes, in the sons of men, in whom there is no salvation. ${ }^{45}$ The same: Accursed is he who trusts in man. ${ }^{46}$ To the more 
vehement urgings he replied that nothing less should be allowed to the judgment of men than the word of God. So they went away saying that they would return before lunch so that he could deliberate how he would reply better.

After lunch they returned; they attempted in vain the same thing which [they had attempted] before Noon. They begged that he submit his writings at the least to the judgment of a future Council. Luther allowed this, but on this condition: that they themselves should show the excerpted Articles from his own books which would be submitted to the Council, but in such a way that they draw their view of these from the Scriptures and that they prove the contrary from the same testimonies.

And so after those men left Dr Martin, they told the Archbishop of Trier that Martin promised that he would commit his writings to the Council, in some Articles, and meanwhile he would be silent about them. Which Dr Martin had never considered, he who could never be persuaded either by any warnings or threats to want either to renounce his Books or submit them to the judgment of men, books which he had fortified by clear and evident Scriptural testimonies, unless it were proven incontestably by sacred writings and plain arguments that he had erred.

So it happened by a singular gift of God that the Archbishop of Trier personally summoned Dr Martin, wishing to speak to him face to face. When, since he had perceived a contradiction which Peutinger and Baden had said, he asserted that he would not undertake a costly case, unless he had listened to him: For otherwise he was about to approach the Emperor at once and would say what the Doctors had reported.

The Archbishop of Trier in fact acted most mercifully toward Dr Martin, first, by removing all the witnesses, both from the Emperor and the Empire and in particular from the court of the Council. Dr Martin concealed nothing from Trier in this conversation, maintaining that it would hardly be safe to entrust so great a matter to those men who, after attacking with new commands the one called forth under the protection of safe conduct, condemned his own opinion and approved the Bull of the Pope.

Then after his friend was admitted, the Archbishop of Trier asked for remedies from Dr Martin with which he would be able to answer this case. Luther replied: 'There are not better remedies than about which Gamaliel in Acts 5 has said, according to St Luke, If this need the counsel of men, let it be dissolved, If in truth it is from God, ye will not be able to dissolve it. ${ }^{47}$ The Emperor and the ranks of the Empire can write to the Roman Pontiff that they know for certain that if this proposition of his is not from God, it will perish of its own accord within three, nay, two years.'

When Trier said what would he do, if the Articles were taken to be submitted to the council, Luther replied: 'Provided they are not those which the Council of Constance condemned.' The Archbishop of Trier said that he indeed feared that those very ones would be submitted. Yet Luther said: 'I am neither able nor willing to be silent about such a thing, as I am certain that the word of 
God was condemned by those Decrees. Accordingly I would rather lose my life and head than abandon such a clear word of the Lord.'

The Archbishop of Trier, seeing that Dr Martin would by no means submit the word of God to the judgment of men, dismissed him mercifully, and he replied to him asking to obtain a merciful leave for himself from the Imperial Majesty: 'I will properly take care of the thing and I will carry back word of it.'

And so not much after, the Official of Trier, in the presence of chancellor Maximilian, Secretary to the Emperor, told Dr Martin in his own lodging, by the command of the Emperor, that because he had been admonished so many times by the Imperial Majesty, Electors, Princes, and the Orders of the Empire, in vain, and did not want to restore himself to sense and wholeness, it remains for the Emperor (as Advocate of the Catholic faith) to proceed. So the command of the Emperor is that he return within twenty-one days hence, to remain in his own care under the protection of the safe passage and not to upset the commons on the way by neither preaching or writing.

When he heard this, Dr Martin most modestly replied, 'Just as it was pleasing to the Lord, so this was done, Let the name of the Lord be praised.' Then he added that first of all, he, a suppliant, gave thanks to the Most Serene Imperial Majesty, Princes, and remaining Orders of the Empire, as greatly as he could for so kind and tolerant a hearing, and for the safe conduct both for coming and going. For he neither desired anything in them, except the reformation through sacred scripture that he so greatly called for. Otherwise he would suffer everything for the Imperial Majesty and the Empire, life and death, fame and ill repute, retaining absolutely nothing for himself, except the unique free word of the Lord in order to confess and bear witness for that: Finally, most humbly commending himself to the Imperial Majesty and the entire Empire and subjecting himself to it.

So the next day, that is, the Friday after Jubilate, on the 26th day of April, after he said goodbye to his Patrons and friends, who had most frequently visited him, and had breakfast, he departed at the tenth hour before noon, accompanied by those who had set out with him on his way there, whom Caspar Sturm the Herald after some hours following found at Oppenheim, Sturm pursuing according to the spoken command of the Emperor Charles.

The usual daily PRAYER of Luther:

Strengthen God that in us which you have worked and complete your work which you have begun in us, for your glory, Amen.

\section{Philip Melan[ch]thon To the Students of the School at Wittenberg, in the Year 1546. On the death of Luther.}

Dr Philip Melanchthon publicly recited these following words at the ninth hour before lunch, when we had assembled for a reading of Paul's Epistle to the Romans, remembering that he did this on the advice of other Lords, for this reason, so that reminded about the truth of the matter we would not 
embrace those fictions being scattered (because they knew that many tales were circulating here and there about the death of Luther).

O Best Young Men, you know that we have undertaken to comment on the grammatical explication of the Epistle to the Romans, in which is contained the true doctrine about the Son of God, which God with singular benefit revealed at this time to us through our most beloved Reverend Father and Teacher Dr Martin Luther.

But on this day, the writings are so sad they have so increased my grief, that I do not know whether I am able to continue hereafter in these scholastic endeavors here: However, I therefore wish to recall these to you on the advice of other Lords, so that you may know how the matter truly is, so that you yourselves neither spread falsehoods about this death nor have faith in other tales spread here and there (as is accustomed to be done).

On the day of Mercury (Wednesday), which was 17 February, Lord Doctor, a little before dinner, began to labor under the customary illness, namely, the pressure of humors in the orifice of the stomach (under which I remember he also labored several times); this sickness recurred after dinner, with which when he struggled, he sought solitude in the nearest bedroom: And, he slept there for close to two hours, until the pains increased. And since Dr Jonas ${ }^{48}$ was sleeping along with him in the same room, Lord Dr Martin called and woke him, and told him to get up and make sure that Ambrose, Pedagogue of the Children, heat the room since he would go in there.

Soon Albert, Count from the nobles of Mansfeld, came there along with his wife and many others, whose names have not been mentioned in this writing on account of the haste.

At last when he sensed that the end of his life was present, before the fourth hour of the following 18 February he commended himself to God with this prayer.

Mein Himlischer Vater ewiger Barmhertziger Gott Du hast mir deinen lieben Sohn unsern HERREN Ihesum Christum oVenbaret den hab ich gelert, den hab ich bekandt den liebe ich, und den ehre ich für meinen lieben Heylandt und Erlöser, Welchen die Gottlosen verfolgen, schenden und schelten. Nim meine Seele zu dir. Inn dem redet er inn die drey mal: In manus tuas commendo Spiritum meum, redemisti me Deus veritatis. Unso hat Gott die welt geliebet $x$.

[My Heavenly Father, eternal Compassionate God, you have revealed to me your beloved Son our LORD Jesus Christ whom I have known, of whom I have acquaintance, whom I love, and whom I honor as my beloved Savior and Redeemer, whom the Godless persecute, dissipate, and reproach. Take my Soul to you. This he said three times: 'Into your hands I commend my Spirit, you have redeemed me God of truth. And God so loved the world, etc.']

After repeating these prayers several times, he was called by God into the everlasting School and into everlasting joys, in which he enjoyed the company of the Father, Son, Holy Spirit, and of all the Prophets and Apostles. 
Ach! the Charioteer and the chariot Israel died, who guided the Church in this last age of the world: for the doctrine of the Remission of sins and the pledge of the Son of God was not apprehended by human sagacity, It was revealed by God through this man, Whom we saw was roused even by God.

Accordingly let us cherish the memory of this Man and the type of Doctrine handed down by himself and let us be modest and let us consider the enormous calamities and great changes which followed this death.

I pray You O Son of God, Emanuel crucified for us and resurrected, guide, preserve, and protect your Church, Amen. ${ }^{49}$ 